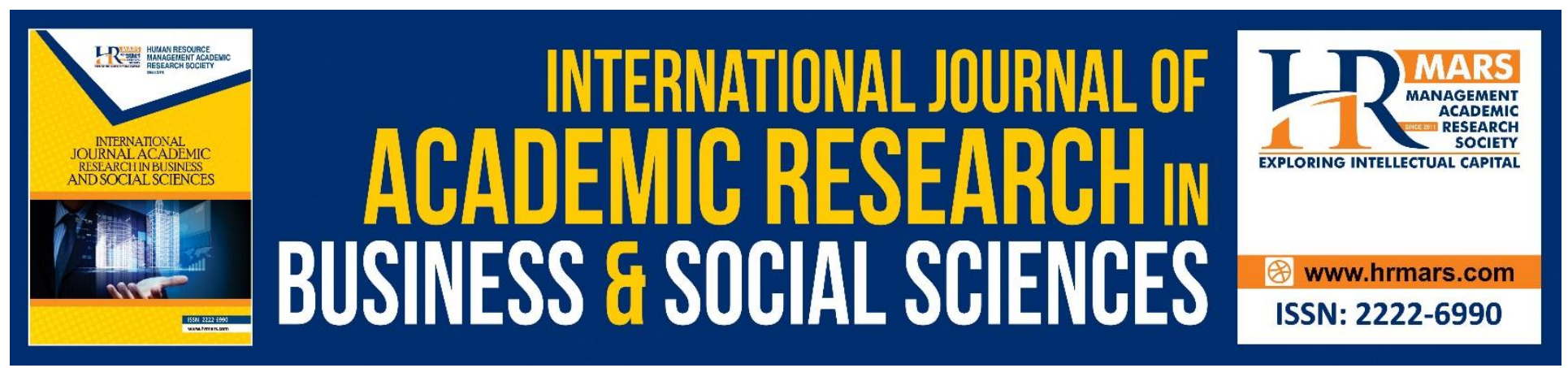

\title{
Cyberbullying among Malaysian Youth: The Case of Selangor
}

\author{
Nurul Farhana Saharrudin, Akmar Hayati Ahmad Ghazali, \\ Asnarulkhadi Abu Samah, Aminah Ahmad, Haslinda Abdullah
}

To Link this Article: http://dx.doi.org/10.6007/IJARBSS/v9-i3/5761

DOI: $\quad 10.6007 /$ IJARBSS/v9-i3/5761

Received: 09 March 2019, Revised: 27 March 2019, Accepted: 05 April 2019

Published Online: 13 April 2019

In-Text Citation: (Saharrudin, Ghazali, Samah, Ahmad, \& Abdullah, 2019)

To Cite this Article: Saharrudin, N. F., Ghazali, A. H. A., Samah, A. A., Ahmad, A., \& Abdullah, H. (2019).

Cyberbullying among Malaysian Youth: The Case of Selangor. International Journal of Academic Research in Business and Social Sciences, 9(3), 1060-1070.

Copyright: (C) 2019 The Author(s)

Published by Human Resource Management Academic Research Society (www.hrmars.com)

This article is published under the Creative Commons Attribution (CC BY 4.0) license. Anyone may reproduce, distribute, translate and create derivative works of this article (for both commercial and non-commercial purposes), subject to full attribution to the original publication and authors. The full terms of this license may be seen

at: http://creativecommons.org/licences/by/4.0/legalcode

Vol. 9, No. 3, 2019, Pg. 1060 - 1070

http://hrmars.com/index.php/pages/detail/IJARBSS

JOURNAL HOMEPAGE

Full Terms \& Conditions of access and use can be found at http://hrmars.com/index.php/pages/detail/publication-ethics 


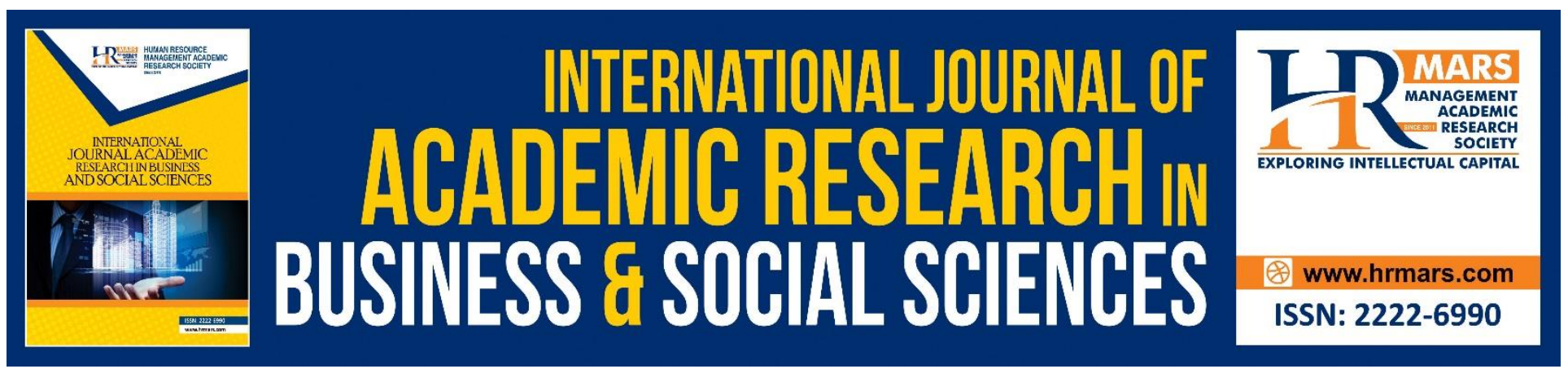

\title{
Cyberbullying among Malaysian Youth: The Case of Selangor
}

\author{
Nurul Farhana Saharrudin ${ }^{1}$, Akmar Hayati Ahmad Ghazali², \\ Asnarulkhadi Abu Samah", Aminah Ahmad', Haslinda Abdullah ${ }^{1}$ \\ ${ }^{1}$ Institute of Educational Studies, Universiti Putra Malaysia, 43400, Serdang, Selangor, Malaysia \\ ${ }^{2}$ Faculty of Modern Language and Communication, Universiti Putra Malaysia, 43400, Serdang, \\ Selangor, Malaysia
}

\begin{abstract}
This study aims to identify Selangor youth's engagement in cyberbullying activities. The study was carried out by a cross-sectional survey of 400 youths in four districts in Selangor namely, Hulu Langat, Serdang, Sabak Bernam and Klang. The study found that Selangor youth's engagement in cyberbullying activities to be at low level. The findings also indicated that the most common form of cyberbullying activity committed among this particular group of youth was to block others in instant messaging application such like WhatsApp, Facebook, Messenger and etc. Several recommendations are made to overcome this social problem, quite a few actions were highlighted to take into consideration such as parental monitoring, cyber education, counselling, media awareness and campaign and the role of internet providers.
\end{abstract}

Keywords: Cyberbullying, Youth, Youth Development; Social problem

\section{Introduction}

Globally, people enjoy better access to communication technologies such as email, blogs, chat applications, and social networking through smartphones or laptop/PC. In line with the rapid evolution of these technologies, people are proned to be exposed to several social problems, among those who are easily affected is youth. According to Cankaya (2010), Eski (2012) and Tpocu, et.al (2010), due to the advancement of internet usage and communication gadgets, youths are highly exposed to cyberbullying activities. Cyberbullying can simply be defined as bullying via communication technologies through smartphones, emails, instant messaging, and social networking's. The aim of cyberbully perpetrators is to disrupt or intimidate other individuals via message or expressions online (Brady, 2010). Normally, cyberbullies will send messages/information with intention to hurt, to humiliate, and degrade their victims.

The existence of social networking sites has attracted internet usage among youths whereby the virtual world has exposed them to the risks of cyberbullying, which has the potential to affect anyone 
involved. According to $\mathrm{Li}$ (2006), the evolution of technology culminates the trend of negative behaviors in the virtual world and eventually it has been the forefront of social problems, one of them is cyberbullying. A study by the Global Youth Online Behavior Survey (Microsoft survey) on 7,600 children aged between 8 to 17, they have demonstrated that one out of every three children in Malaysia were victims of cyberbullying. The study also concluded that the level of awareness on cyberbullying awareness among parents in Malaysia was low only $38 \%$ of the parents were concerned about the issue while slightly more than a quarter have talked to their children about the risks of online communication.

The difference between traditional bullying and cyberbullying is the fact that virtual bullying has no boundary compared to the physical world. The anonymity of the online bullies and the speed it offers have embolden youths to engage in cyberbullying activities. In addition to the cause, scholars have placed their interests on the impact cyberbullying among youths. Based on past research on cyberbullying, some of researches have discussed on the negative impacts of cyberbullying. Bauman (2012) for example, concluded that cyberbullying victims generally undergo stress and anxiety, which later would affect their academic performance. (Goddard, 2008) has specifically focused on female cyberbully victims and concluded that most of them were distracted in their study after being cyberbullied. Meanwhile, Erdur-Baker and Tanrikulu (2010), and Ybarra and Mitchell, (2004) found cyberbully victims to be emotionally unstable and tend to demonstrate aggressive behavior in the future.

Despite continuous and rigorous efforts of global studies conducted to understand cyberbullying in a bigger scale. Up till now, it remains unclear why cyberbullying still occur since the issue does not entail a solid understanding on the persistence in cyber harassment. Hence, this study aims to fill the gap by looking into Malaysian youths' engagement Malaysia in cyberbullying activities, particularly in - Selangor. This study will discuss in detail, the level of their cyberbullying engagement and the types of cyberbullying activities involved, later several highlighted to prevent cyberbullying.

\section{LITERATURE REVIEW}

One study conducted by Balakrishnan (2015) has aimed to explore cyberbullying issues among young adults. In this study has survey around 393 youth (aged $17-30$ years old) in Malaysia. He concluded that internet usage frequency could initiate cyberbullying among youths while the internet and existing social networking sites could instigate cyberbullying among Malaysian youth. These findings has correspondingly confirmed that cyberbully victims have a tendency to become cyberbully themselves or otherwise.

The study of Ang (2015) summarizes the features, prevention strategies and interventions for cyberbullying issues. The conclusions of this study are the frequency in which internet use plays an important role in the occurrence of cyberbullying and highlights its cause, which is proactive aggressive, weak relationships between parents and their children. (2015) proposes empathy training and modifies beliefs that support intrusion, guidelines for internet usage behavior and develop strong and positive bonds of teens as almost tactics to combat cyberbullying.

The study by Hawker and Boulton (2000) and Blanchard (2011) there are several types of cyberbullying, the impact and prevention strategy. Blanchard (2011) confirmed the dating violence, abuse and distribution of text messages that interfere with personal information on social media sites 
as the most frequently conducted by cyberbullying. This behavior can lead to upward pressure, conflict, social anxiety, sadness and disappointment. In the study by Hawker and Boulton (2000), they found that cyberbullying can cause extreme effects such as suicide victims. To prevent cyberbullying, Blanchard (2011) stressed the importance of technology in solving cases cyberbully while the role of social service workers and law enforcement needs to be authorized.

\section{METHODOLOGY}

This study was questionnaire carried out by a cross-sectional survey consisting of 38 items to measure cyberbullying engagement among youth. For each item, the respondents were given a five Likert scale of answer ranging from 0 (never) to 4 (always). In addition to the cyberbullying engagement items, the instrument also surveys their demographic background and internet usage pattern. Prior to the actual data collection, a pilot study was conducted to test the instrument's reliability. The instrument's resulted Cronbach alpha value is .888 , which passed the recommended value of .700 by Nunally (1978). Based on the margin error of $5 \%$ and confidence level are $95 \%$, the Rao soft statistical sampling tools suggested a maximum total of 377 respondents. This study however, aims for a bigger sample of 400. A multi cluster sampling was performed and via this procedure, 400 youths aged between 15 to 40 years old were selected as respondents. The data collection process was conducted around four districts in Selangor namely Sabak Bernam, Klang, Hulu Langat and Serdang Selangor. Each district was represented by 100 respondents. SPSS was used to analyse the frequency, percentage and mean score.

\section{RESULT}

\section{Respondents' Demographic Background}

Table 1 demonstrates the respondents' demographic background. The sample consists of $50.2 \%$ female respondents and $49.8 \%$ male respondents. The mean age of the sample was 21.2 and most of them fall into the age group of 20-22 (39.0\%) age group. Regarding their educational achievement, most of them possessed skill certificates/STPM and Degree/Master/PhD (31.3\%), followed by those with SPM/SPMV (26.0\%). In terms of their employment status, slightly more than $70 \%$ were unemployed. Their average household income was RM3491.96 with $19.8 \%$ earning more than RM4,001 a month. Furthermore, 39.8\% of the respondents had between 5-6 household members while another $36.8 \%$ had 4 household members or less. 
INTERNATIONAL JOURNAL OF ACADEMIC RESEARCH IN BUSINESS AND SOCIAL SCIENCES

Vol. 9, No. 3, March, 2019, E-ISSN: 222 2-6990 @ 2019 HRMARS

Table 1: Respondents' Demographic background

\begin{tabular}{|c|c|c|c|}
\hline Factor & Frequency & Percentage & Mean Score \\
\hline \multicolumn{4}{|l|}{ Gender } \\
\hline Male & 199 & 49.8 & \\
\hline Female & 201 & 50.2 & \\
\hline Age & & & 21.2 \\
\hline 19 years and below & 142 & 35.5 & \\
\hline $20-22$ years & 156 & 39.0 & \\
\hline 23 years and above & 102 & 25.5 & \\
\hline \multicolumn{4}{|l|}{ Education achievement } \\
\hline Never been to school & 6 & 1.5 & \\
\hline Primary school & 7 & 1.8 & \\
\hline PMR & 16 & 4.0 & \\
\hline SPM/SPMV & 104 & 26.0 & \\
\hline Skill certificates/STPM & 125 & 31.3 & \\
\hline Diploma & 17 & 4.3 & \\
\hline Degree/Master/PhD & 125 & 31.3 & \\
\hline \multicolumn{4}{|l|}{ Working status } \\
\hline Employed & 117 & 29.3 & \\
\hline Unemployed & 283 & 70.7 & \\
\hline Household income $(n=346)$ & & & RM3491.96 \\
\hline RM1000 or less & 71 & 17.8 & \\
\hline RM1001-RM2000 & 103 & 25.8 & \\
\hline RM2001-RM4000 & 93 & 23.3 & \\
\hline RM4001 or more & 79 & 19.8 & \\
\hline \multicolumn{4}{|l|}{ Number of household members } \\
\hline 4 or less & 147 & 36.8 & \\
\hline $5-6$ & 159 & 39.8 & \\
\hline 7 or more & 94 & 23.5 & \\
\hline
\end{tabular}

Internet Usage Background

Table 2 depicts the respondent's internet usage pattern. The resulted mean score for internet usage experience was 6.4 years due to $54.7 \%$ of them have spent 6 years of long periods of time in using it, which confirmed their proficiency in using the internet. More than three quarter of them (82.5\%) have subscribed to internet services they preferred to surf the internet at (52.5\%). On average, the respondents spent about 10.5 hours a day on the internet with $26.8 \%$ of them spent between $8-12$ hours a day. The respondents usually surf the internet at night. 
INTERNATIONAL JOURNAL OF ACADEMIC RESEARCH IN BUSINESS AND SOCIAL SCIENCES

Vol. 9, No. 3, March, 2019, E-ISSN: 2222-6990 @ 2019 HRMARS

Table 2: Patten of internet usage

\begin{tabular}{|c|c|c|c|}
\hline Factor & Frequency & Percentage & Mean Score \\
\hline Experience in using the internet & & & 6.4 years \\
\hline 3 years or less & 98 & 24.5 & \\
\hline 4 to 5 years & 83 & 20.8 & \\
\hline 6 years or more & 219 & 54.7 & \\
\hline \multicolumn{4}{|c|}{ Subscribed to any internet services? } \\
\hline Yes & 330 & 82.5 & \\
\hline No & 70 & 17.5 & \\
\hline \multicolumn{4}{|l|}{ Main place to use the internet } \\
\hline Home & 210 & 52.5 & \\
\hline Work place & 44 & 11.0 & \\
\hline Cyber cafe & 22 & 5.5 & \\
\hline Educational institution & 106 & 26.5 & \\
\hline Public area & 18 & 4.5 & \\
\hline \multicolumn{4}{|l|}{ Main time to use the internet } \\
\hline Morning & 25 & 6.3 & \\
\hline Afternoon & 38 & 9.5 & \\
\hline Evening & 35 & 8.8 & \\
\hline Night & 111 & 27.8 & \\
\hline Every time & 191 & 47.8 & \\
\hline Time used for internet usage & & & 10.5 hours \\
\hline 3 hour or less & 80 & 20.0 & \\
\hline 4-7 hour & 100 & 25.0 & \\
\hline 8-12 hour & 107 & 26.8 & \\
\hline 13 hour or more & 113 & 28.3 & \\
\hline
\end{tabular}

4.3 Overall mean for score cyber bully

Table 3 showed the overall mean score of cyberbullying. Based on the range of score calculation, the level of mean score was pooled into three categories namely low (0-1.33), moderate (1.34-2.66) and high (2.67-4.00). Interestingly, the results confirmed that majority of youth in Selangor (90.0\%) were eventually engaged in cyberbullying but only at a low level. The overall mean score recorded of cyberbullying activities is $\mathrm{M}=.052$. Table 3: Overall mean score Cyber bully

\begin{tabular}{llll}
\hline Level & Frequency & Percentage & Mean score \\
\hline Low (0-1.33) & 360 & 90.0 & 0.52 \\
Moderate (1.34-2.66) & 34 & 8.5 & \\
High (2.67-4.00) & 6 & 1.5 & \\
\hline
\end{tabular}

Cyberbullying among youth in Selangor

The study concluded that blocking others in instant messaging application ( $M=1.33$ ) was one of the most common act of cyberbullying amongst youth. Others than blocking other online, ignoring others 
INTERNATIONAL JOURNAL OF ACADEMIC RESEARCH IN BUSINESS AND SOCIAL SCIENCES

Vol. 9, No. 3, March, 2019, E-ISSN: 222 2-6990 ¿ 2019 HRMARS

$(M=0.96)$, condemning someone and using slang while instant messaging them $(M=0.91)$ and intention to remove someone from online group chats or instant messaging application $(M=0.88)$ were the common form of cyberbullying. Further analysis has confirmed that youth were less engaged scamming activities, getting other people's personal information and post it on the Web $(M=0.30)$, conducting sexual harassment to others by phone or internet $(M=0.30)$ and or stealing webcam image of other people without their permission $(M=0.30)$.

Table 4: Statements that defined cyberbullying

STATEMENTS

Blocking others in instant messaging application

Ignoring others

Condemn and using slang while using instant messaging applications

Intend to remove someone from an online group chat or instant messaging applications

Specifically and purposefully remove other group members of the member group in online chats or instant messaging apps

Bullying someone in an online social utility because of their physical appearance or their character

Do not allow others to participate in a conversation

Send religious or political messages without permission

Hide my identity when communicating with others

Invite others to join social applications containing gossip or inappropriate chats

Write something bad about someone else

Use software to obtain other people's personal information

Pretend to be someone else in the virtual world

Send harassment word through email or instant message to others

Send an email or instant message containing insults

Make calls for the purpose of scaring others

Steal or get someone else's password

Talk on behalf of others by stealing their nickname without their knowledge

Send an email or instant message containing lies and something bad about someone

else

Disturbing others and forcing them to chat via instant messaging applications

Publish pictures and personal videos of others without their permission

Share other people's personal information of others online without their permission

Send threatening email or instant messages

Send unwanted content into other people's computers without their permission

Slandering others via the internet, spreading rumours with the intention of humiliating them

Send pornographic information to the people I know or not know

Spreading rumors that may affect you

Threatening others through calls or messages

Urged people to vote or sign the political groups, sports groups or religious groups

Using someone else's personal information without their permission
1.33

0.96

0.91

0.88

0.78

0.77

0.76

0.75

0.64

0.64

0.64

0.56

0.55

0.54

0.50

0.47

0.47

0.47

0.45

0.43

0.43

0.42

0.39

0.39

0.39

0.38

0.38

0.38

0.37

0.37 
INTERNATIONAL JOURNAL OF ACADEMIC RESEARCH IN BUSINESS AND SOCIAL SCIENCES Vol. 9, No. 3, March, 2019, E-ISSN: 222 2-6990 ¿ 2019 HRMARS

Editing photos or video and share them online or upload on You Tube with the intention to ridicule them

Publish other personal information via email or instant messaging without their

permission

Threaten others by forcing them to do things they do not like, such as preventing you

from spreading their personal things online

View pornographic images through Webcam

0.32

Send pornographic emails

0.31

Scam other to get their personal information and post it on the Web

0.30

Conduct sexual harassment to others through phone or the internet

0.30

Use a webcam image of another person without their permission

0.30

\section{Discussion and Recommendation}

Result show that $10.0 \%$ of youth in Selangor have moderately engaged in cyberbullying activities. The results are somewhat different to other countries. Baldry et al. (2019) for example, has concluded that $29.2 \%$ of youth in Italy were engaged in cyberbullying, Martínez-Monteagudo et al. (2019) confirmed that $19.4 \%$ youth in Spain have cyberbullied others, Yang et al. (2018) found $17.6 \%$ of youth in China were the perpetrators of cyberbullying, Jenaro et al. (2018) noted that $15.2 \%$ of Chilean youth have engaged in cyberbullying, meanwhile Leung et al. (2018) in their study have reported as high as 58\% of Hong Kong Chinese students were involved in cyberbullying.

Within the scope of this study, the most committed forms of cyberbullying were blocking others in instant messaging application, ignoring others, condemning and using slang while messaging online. The study shows a contrast finding to Martínez-Monteagudoa et al. (2019), Yang et al. (2018) and Leung et al. (2018) who found youth engagement in cyberbullying were mostly related to teasing someone, calling someone with bad names, say mean things about someone, aiming to hit or hurting someone, threatening someone, and spreading rumors about someone in order to make others loathe them. Several factors are found to be the cause of this diversity.

Shin and Ahn (2015) for example, found that youth who spent more time playing games during weekdays, being active mobile phone users, and possesses high confidence in cyberspace were more likely to be involved in cyberbullying. Lee and Shin (2017) then confirmed that the male and the amount of time they spent on online games and chat services, increase the possibility of them getting involved in cyberbullying. Gámez-Guadix and Gini (2016) on the other hand, investigated the influence of age and the desire to enhance one's peer status to be the strongest influence on committing cyberbullying.

Although Selangor youth's involvement in cyberbullying activities was found to be low precautionary actions and proactive planning are needed to ensure that this particular social issue do not get out of hand. This study has come out with several recommendations that can related to cyberbullying issues which is parental monitoring, cyber education, counselling, media awareness and campaign and most of all the important role played by internet providers.

Parents play a vital role in preventing cyberbullying activities. In the era where the pace of technological evolution, as the main users of internet in Malaysia, youths are easily exposed to cyberbullying activities. Every parent should supervise and monitor their children's online activities, 
take precautions against cyberbullying activities, educate their children on the dos and don'ts in the virtual space by informing them on impact of cyberbullying.

Cyber education is an important part of virtual communities. Hinduja and Patchin (2008); Patchin and Hinduja (2009); Patchin and Hinduja (2010) have agreed on the importance of cyber education as a remedy to overcome social issue such as cyberbullying. Cyber education includes information of the ethics of using computer, online security and safety, privacy violations, and mostly limiting personal information sharing. These are the main points that should be taught to youth.

Counselling can be a systematic avenue to support individuals and learn how to protect themselves online (Carter, 2013). Among the topics highlighted by (Carter, 2013) are the development of a repertoire of leisure time skills, debrief regarding the after exposure or perpetration to cyber bullying and regulating behaviors in need satisfying ways.

Media offers a good and a bad side of things related to youth development. Despite the increasing possibility of youth's involvement in cyberbullying, media can be utilized to enhance people's awareness on the impact of cyberbullying. A media awareness campaign is a strong platform to remind people on the risks of cyberbullying. Online forums can be used to educate youths on cyber bullying including and spread information on the motives for cyberbullying, its impacts and measures to take for those who are victims of cyberbullies. Furthermore, several social media sites enable users to block perpetrators, if they feel uncomfortable virtually.

Based on Carter (2013) study, internet service provider hold responsibility in adopting codes and policies on online safety to prevent youth from being susceptible to becoming victims of cyberbullying. Understandably, online users are given the choice to report any online misconducts such as pages containing abusive contents, sexual harassment, scams or violent threats by clicking on the report button online or contact the website operator. Every parties has responsible and play role to prohibit cyberbully issues from new incoming generation.

\section{Conclusion}

Cyberbullying is an emerging issue that causes inflictions and imposes negative implications if not taken seriously by all parties. In this study aims to identify Selangor youth's engagement in cyberbullying activities. The study found that Selangor youth's engagement in cyberbullying activities to be at low level. The findings also indicated that the most common form of cyberbullying activity committed among this particular group of youth was to block others in instant messaging application such like WhatsApp, Facebook, Messenger and etc. All related parties inclusive of parents, teachers, educators and communities should create a positive social environment that is able to prevent cyberbullying. Parenting awareness especially, is crucial to ensure their children's safety whether physically or virtually. More efforts should be made to reduce and prevent the cyberbullying as it could risk the health and well-being of youths today. Future research should focus on the identifying cyberbullying factors, which is important for the future development of youth.

\section{Acknowledgment}

The research team would like to thank Ministry of Higher Education Malaysia for providing Fundamental Research Grant Scheme for this study. (05-01-16-1870FR) 
INTERNATIONAL JOURNAL OF ACADEMIC RESEARCH IN BUSINESS AND SOCIAL SCIENCES

Vol. 9, No. 3, March, 2019, E-ISSN: 222 2-6990 @ 2019 HRMARS

\section{References}

Bauman, S. (2012). Cyberbullying. Encyclopedia of diversity in education, Sage publication, Inc. Brady, K. P. (2010). Cyberbullying. Encyclopedia of law and higher education, Sage publication, Inc. Cankaya, I. T. (2010). Effect of cyber bullying on the distrust level of preservice teachers: Considering internet addiction as a mediating variable. Procedia computer science 3, 1353 - 1360.

Carter, M. A. (2013). Third party observers witnessing cyber bullying on social media sites. Procedia social and behavioral science 84, 1296-1309.

Costanza, A., Sorrentino, A., \& Farrington, D. P. (2019). Cyberbullying and cybervictimization versus parental supervision, monitoring and control of adolescents' online activities. Children and Youth Services Review, 96 (August 2018), 302-307.

https://doi.org/10.1016/j.childyouth.2018.11.058

Erdur-Baker, O. \&. (2010). Psychological consequences of cyber bullying experiences among Turkish secondary school children. Procedia Social and Behavioral Sciences, 2, 2771 - 2776.

Eski, F. (2012). Examination of narcisistic personality traits' predicting level of internet addiction and cyber bullying through path analysis. Educational science: theory and practice, 2771 - 2776.

Goddard, C. (2008). "Cyber world bullying". Education Digest, 73(7), 4 - 9.

Gámez-guadix, M., \& Gini, G. (2016). Individual and class justi fi cation of cyberbullying and cyberbullying perpetration: A longitudinal analysis among adolescents. Journal of Applied Developmental Psychology, 44, 81-89. https://doi.org/10.1016/j.appdev.2016.04.001

Jenaro, C., Flores, N., Vega, V., Cruz, M., Carmen, M., \& Torres, V. A. (2018). Research in Developmental Disabilities Cyberbullying among adults with intellectual disabilities: Some preliminary data. Research in Developmental Disabilities, 72(October 2017), 265-274. https://doi.org/10.1016/j.ridd.2017.12.006

Hinduja, S. \&. (2008). Cyberbullying: An exploratory analysis of factors related to offending and victimization. Deviant Behavior, 29(2), 1 - 29.

Li, Q. (2006). Cyberbullying in schools: a research of gender differences. School psychological international, 157 - 170.

Lee, C., \& Shin, N. (2017). Prevalence of cyberbullying and predictors of cyberbullying perpetration among Korean adolescents. Computers in Human Behavior, 68, 352-358. https://doi.org/10.1016/j.chb.2016.11.047

Martínez-monteagudo, M. C., Delgado, B., Inglés, C. J., \& García-fernández, J. M. (2019). Cyberbullying in the university setting. Relationship with family environment and emotional intelligence. Computers in Human Behavior, 91(May 2018), 220-225. https://doi.org/10.1016/j.chb.2018.10.002 Nga, A., Leung, M., Wong, N., \& Farver, J. M. (2018). Cyberbullying in Hong Kong Chinese students: Life satisfaction, and the moderating role of friendship qualities on cyberbullying victimization and perpetration. Personality and Individual Differences, 133, 7-12. https://doi.org/10.1016/j.paid.2017.07.016

Patchin, H. \&. (2009). Bullying beyond the schoolyard: Preventing and responding to cyberbullying. Thousand Oaks, CA: Sage Publications.

Patchin, S. H. (2010). Bullying, cyberbullying and suicide. International academy for suicide research, $206-221$. 
Shin, N., \& Ahn, H. (2015). Factors Affecting Adolescents' Involvement in Cyberbullying: What Divides the 20\% from the 80\%? Cyberpsychology Behavior Social Network. 18(7):393-399. https://doi/10.1089/cyber.2014.0362

Topcu. C., \&. E.-B. (2008). The revised cyber bullying inventory (RCBI): validity and realibility studies. Procedia social and behavioral science, 5, 660 - 664.

Yang, X., Wang, Z., Chen, H., \& Liu, D. (2018). Cyberbullying perpetration among Chinese adolescents: The role of interparental conflict, moral disengagement, and moral identity. Children and Youth Services Review, 86 (February), 256-263. https://doi.org/10.1016/j.childyouth.2018.02.003 Ybarra, M. \&. (2004). Online aggressor/targets, aggressors, and targets: A comparison of associated youth characteristic. Journal of Child Psychology and Psychiatry, 1308-1316. 